\section{RICYDE. Revista Internacional de Ciencias del Deporte doi: $10.5232 /$ ricyde \\ Rev. Int. cienc. deporte}

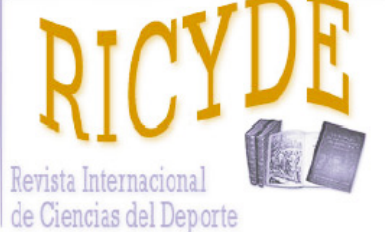

RICYDE. Revista Internacional de Ciencias del Deporte Volume XVI - Year XVI

Pages: $330-341$ - ISSN: $1885-3137$

Issue 61 - July 2020

\title{
Anthropometric and conditional profile in semiprofessional futsal players: differences between sexes. A case study \\ Perfil antropométrico y condicional en jugadores semiprofesionales de futbol sala: diferencias entre sexos. Un estudio de caso
}

\author{
Carlos Lago-Fuentes ${ }^{1}$, Sergio Pérez-Celada ${ }^{2}$, Javier Prieto-Troncoso ${ }^{2}$, Ezequiel Rey ${ }^{2} \&$ \\ Marcos Mecías-Calvo ${ }^{1}$
}

1. Facultad de Ciencias de la Salud, Universidad Europea del Altántico. España

2. Facultad de Ciencias de la Educación y del Deporte, Universidad de Vigo. España

\begin{abstract}
Anthropometrical profile is one of the indicators associated to optimal performance of futsal players. However, no studies have analyzed these factors in both sexes neither created an anthropometrical profile of each sex. For these reasons, the goals of this study were: to describe and compare the anthropometric and conditional profiles of sub-elite futsal players, and to analyze possible correlations between anthropometric and conditional parameters. 11 female and 8 male sub-elite futsal players participated in the study. Several tests were performed: an anthropometric and body composition analysis, leg power with squat jump (SJ) and countermovement jump (CMJ) tests, and psoas and major gluteus flexibility test. Male futsal players reported a better performance in SJ and CMJ ( $p<0.001$, big ES), as well as a lower fat percentage (10.2\%) and a greater muscular percentage $(50.8 \%)$ than female futsal players $(20.1 \%$ and $44.9 \%$, respectively). No significant differences were found regarding flexibility between sexes ( $p>0.05$ ). Fat percentage presents a reversal correlation ( $r=-0.84$; ES very large), as well as muscular performance, a direct correlation ( $r=0.73$; ES very large) with explosive performance. There are significant differences between sexes regarding anthropometric and leg power parameters, not in flexibility values. Finally, the training methods and conditional goals along the season should be adapted to anthropometric and conditional profile of each competitive level, with special focus in neuromuscular performance.
\end{abstract}

Key words: somatotype; range of motion; leg power; sex characteristics.

\section{Resumen}

El objetivo de este estudio fue revisar sistemáticamente el origen y las modificaciones del centro geométrico (GC) en IEl perfil antropométrico es uno de los indicadores asociados al rendimiento óptimo de los jugadores de fútbol sala. Sin embargo, ningún estudio ha analizado estos factores en ambos sexos ni ha creado un perfil antropométrico de cada sexo. Por estas razones, los objetivos de este estudio fueron: describir y comparar los perfiles antropométricos y condicionales de los jugadores de fútbol sala semiprofesionales, y analizar las posibles correlaciones entre los parámetros antropométricos y condicionales. En el estudio participaron 11 jugadoras de fútbol sala semiprofesionales y 8 hombres. Se realizaron varias pruebas: un análisis antropométrico y de composición corporal, potencia de las piernas con salto (SJ) y pruebas de contramovimiento (CMJ), y prueba de flexibilidad del psoas y glúteo mayor. Los jugadores de fútbol sala masculinos reportaron un mejor rendimiento en SJ y CMJ ( $p<0.001$, ES grande), así como un menor porcentaje de grasa $(10.2 \%)$ y un mayor porcentaje muscular $(50.8 \%)$ que las jugadoras de fútbol sala $(20.1 \%$ y $44.9 \%$, respectivamente). No se encontraron diferencias significativas con respecto a la flexibilidad entre sexos ( $>>0.05)$. El porcentaje de grasa presenta una correlación inversa ( $r=-0.84$; ES muy grande), así como el rendimiento muscular, una correlación directa ( $r=0.73$; ES muy grande) con un rendimiento explosivo. Existen diferencias significativas entre sexos con respecto a los parámetros antropométricos y de potencia de las piernas, no en los valores de flexibilidad. En conclusión, los métodos de entrenamiento y objetivos condicionales durante la temporada deben ajustarse al perfil antropométrico y condicional de cada nivel deportivo, con especial foco en el rendimiento neuromuscular.

Palabras clave: somatotipo; rango de movimiento; potencia de piernas; características sexuales.

Correspondence/correspondencia: Marcos Mecías-Calvo

Facultad de Ciencias de la Salud, Universidad Europea del Altántico, España

Email: marcos.mecias@uneatlantico.es 
Lago-Fuentes, C.; Pérez-Celada, S.; Prieto-Troncoso P.; Rey, E., \& Mecías-Calvo, M. (2020). Anthropometric and conditional profile in semiprofessional futsal players: differences between sexes. A case study. RICYDE. Revista Internacional de Ciencias del Deporte. 61(16), 330-341. https://doi.org/10.5232/ricyde2020.06107

\section{Introduction}

$\mathrm{F}$ utsal is a team sport with high intensity actions and several changes of directions with intermittent dynamics (Matzenbacher, Pasquarelli, Rabelo, \& Stanganelli, 2014). During matches, players competed at $85-90 \%$ maximum heart rate, both in male and female teams (Arins, Salvador, Carminatti, \& Guglielmo, 2015; Barbero Álvarez et al., 2015; Castagna, D’Ottavio, Grande Vera, \& Barbero Álvarez, 2009). Also, athletes performed different type of actions per minute with a mean of a high intensity effort every 23 seconds (Barbero Álvarez et al., 2015). These characteristics require a high physical, technical and tactical capability, defining it as an intermittent high-intensity strenuous sport with constant movements and changes of direction that simultaneously requires the aerobic and anaerobic pathways (Arins et al., 2015; Barbero et al., 2009).

Taking this competitive profile into account, some specific key performance factors are needed in this sport. Thus, the power of lower limbs, the oxygen uptake, the body composition (Teixeira et al., 2014) and the range of motion (ROM) (Sainz de Baranda, Cejudo, Ayala, \& Santonja, 2015), can contribute to the optimum performance of the futsal player (Teixeira et al., 2014), as well as to discriminate the performance level (RamosCampo et al., 2016).

The leg power is relevant in futsal players because of its importance on kicking the ball, the changes of direction, accelerations, decelerations, among others (Karavelioglu, Harmanci, Kaya, \& Erol, 2016; Ramos-Campo et al., 2014; Ramos-Campo et al., 2016; Teixeira et al., 2014). An optimal ROM profile has also influence in futsal common actions due to its short, explosive and high requirement actions, like changes of direction, tackling, and others aspects as reducing the injury risk (Ayala, Sainz de Baranda, De Ste Croix, \& Santonja, 2012; Cejudo, Sainz de Baranda, Ayala, \& Santonja, 2014; Sainz de Baranda et al., 2015).

Additionally, anthropometric data are considered good predictors of the sport performance (Galy et al., 2015; Milić et al., 2017). Male futsal players have usually reported a low fat percentage, between 10-16\% in different studies and categories (Da Rocha, Nunes, \& Venera, 2015; Matzenbacher et al., 2014; Rodrigues et al., 2011; Vidal Andreato et al., 2013), showing bigger values for female futsal players (>18\%) (Barbero Álvarez et al., 2015; Da Rocha et al., 2015; Ramos-Campo et al., 2016; Teixeira et al., 2019).

Since futsal is a recent sport in comparison with other modalities, the number of research is relatively small (Naser, Ali, \& Macadam, 2017). Female futsal is growing exponentially during the last years with new international competitions (FIFA, 2018), but with a lot less scientific knowledge than in male counterparts. Consequently, during decades, coaches have trained female athletes with "male rules", but this should be changed (Bruinvels et al., 2017). For these reasons, it is mandatory to define properly the conditional profile for both modalities to, subsequently, design and adapt the training plans to these needs. To the authors' knowledge, no previous studies analyzing these performance factors of both sexes in futsal have been published. Therefore, the aims of the present study were to compare anthropometric and conditional profiles of female and male sub-elite futsal players, and to analyze the correlation between anthropometric profile and performance in leg power. 
Lago-Fuentes, C.; Pérez-Celada, S.; Prieto-Troncoso P.; Rey, E., \& Mecías-Calvo, M. (2020). Anthropometric and conditional profile in semiprofessional futsal players: differences between sexes. A case study. RICYDE. Revista Internacional de Ciencias del Deporte. 61(16), 330-341. https://doi.org/10.5232/ricyde2020.06107

\section{Material and Methods}

\section{Participants}

26 sub-elite futsal players participated in this study, 14 female futsal players $(21.6 \pm 3.6$ years) of Second National Division and 12 male players $(24.8 \pm 5.2$ years $)$ of Second B National Division, after $6.9 \pm 3.1$ years of experience playing in National Spanish futsal leagues. Inclusion criteria were: regular participation in more than the $90 \%$ of sessions in the previous 3 months and "injury absence" during this period (Lago-Fuentes et al., 2018). Finally, 19 players (11 women and $8 \mathrm{men}$ ) passed these criteria and participated voluntarily in the study. Both teams regularly performed 4 weekly sessions with their teams and, on average, they exercised $7.8 \pm 0.5 \mathrm{~h} /$ week, competing also regularly 1 official match per week. All the subjects were informed of the goals of this study and signed their informed consent according to the Declaration of Helsinki. The study was approved by the Investigational Review Committee of The Department of Physical Education and Sport Sciences. Table 1 shows the physical characteristics of futsal players.

Table 1. Descriptive data of futsal players

\begin{tabular}{|c|c|c|c|c|}
\hline \multirow{2}{*}{$\begin{array}{c}\text { Sex } \\
\text { Variable }\end{array}$} & \multicolumn{2}{|c|}{ Female $(n=11)$} & \multicolumn{2}{|c|}{ Male $(n=8)$} \\
\hline & Mean & SD & Mean & SD \\
\hline Weight ${ }^{1}$ & 62.5 & 3.4 & 73.0 & 9.2 \\
\hline Height $^{2}$ & 1.65 & 0.04 & 1.74 & 0.08 \\
\hline $\mathrm{BMI}^{3}$ & 22.9 & 1.6 & 23.9 & 2.2 \\
\hline
\end{tabular}

\section{Procedures}

All the following test were performed 72 hours after a match during the in-season period, in the middle of the season, between $8.30 \mathrm{pm}$ and $9.30 \mathrm{pm}$, before the training session. All the test were carried out on an official futsal court during the same day for each player. This placement was chosen because it is the usual place for the players with the target of facilitate their comfortability and to reduce their uncertainty during the test procedures. The sequence of the test was, as are described below: body composition test, range of motion and leg power following a logical order regarding their demands.

\section{Measures}

\section{Body composition}

Body composition was carried out before the beginning of the testing sessions, it was the first test of the battery. Body mass and height were measured using a scale that was accurate to $0.1 \mathrm{~kg}$ (SECA-711) and a height stadiometer that was accurate to $1 \mathrm{~mm}$ (SECA-264). Anthropometric evaluation was carried out measuring skinfold thickness according to ISAK protocols, by a specialist researcher accredited by ISAK level II. These measurements were taken in triplicate using a plicometer, pachymeter and anthropometric meter (CESCORF) that were accurate to $1 \mathrm{~mm}$. Later, the somatotype was calculated using the formulas defined by ISAK level II protocols (Marfell-Jones, Stewart \& de Ridder, 2012), determining percentages of body fat, muscle mass, bone and residual, as well as the somatochart for both male and female futsal athletes. 
Lago-Fuentes, C.; Pérez-Celada, S.; Prieto-Troncoso P.; Rey, E., \& Mecías-Calvo, M. (2020). Anthropometric and conditional profile in semiprofessional futsal players: differences between sexes. A case study. RICYDE. Revista Internacional de Ciencias del Deporte. 61(16), 330-341. https://doi.org/10.5232/ricyde2020.06107

\section{Range of motion}

Range of motion was evaluated quantifying hip flexion and extension with the following tests: major gluteus flexibility, modifying test of hip flexion with leg straight (Sainz de Baranda et al., 2015). Secondly, iliopsoas flexibility was measured by test with hip extension by the modified version of Thomas test (Sainz de Baranda et al., 2015).

Two attempts were made for each one of the evaluation tests and body section. The order of these tests was made randomly with the purpose of reduce the bias of that a specific sequence could present on the obtained results. However, when a difference greater than the 5\% was observed in each pair of attempts, a third one was made, selecting the average value of both attempts whose results were closer for the subsequent statistical analysis. The randomization of tests was carried out through the use of the computer software Research Randomizer. For the measurement of the ROM, it was used the SAEHAN goniometer. The researcher who performed this ROM evaluation had previous experience in these test.

\section{Leg power}

All the participants performed 10 min of standardized warm-up comprising 2 minutes of light active static stretching (10 repetitions for hamstrings, quadriceps, and calf muscles), and 5 minutes jogging, followed by short distance accelerations with 3 submaximal sprints. This routine was supervised by the team's physical coach before the test. The leg power was evaluated using Squat Jump (SJ) and Counter Movement Jump (CMJ), following the technique explained by Bosco (Bosco, Komi, Tihanyi, Fekete, \& Apor, 1983). Subjects performed SJ and CMJ on a force plate (Chronojump Boscosystem, DinA2), and then the data were computerized to calculate the height and the flight time. The CMJ was performed with a stretch-shortening cycle (SSC) with arms on hip and straight trunk, while the SJ was completed only with the concentric phase starting from a squatted position. Subjects were allowed two trials, with 2-min rest period between jumps of the same type and of different types. Both male and female players had experience in these types of actions.

In the SJ test, the player must perform a vertical jump from a semisquatting position with his/her trunk in upright position and his/her hands in the hips. The player must perform the test without using countermovement; the jump from a stopped position that must be done without arms help constitutes an easy test, of an easy learning and of a high standardization (Bosco et al., 1983). During the performance of the CMJ test, the player gets ready in an upright position with his hands in the hips, following he/she must do a vertical leap after a countermovement (his/her legs ought to reach a bending of $90^{\circ}$ in the knee joint). During the action of the bending, the trunk must be as straight as possible to avoid any influence of itself in the result of the performance of the lower limbs (Bosco et al., 1983). For both test, the best result was recorded to the study.

\section{Statistical analysis}

All variables were normally distributed (Shapiro-Wilk test). Data are presented as means with standard deviation (SD). Statistical analysis was performed using SPSS for Windows (20.0, Chicago, IL, USA). Statistical significance was set at $\mathrm{p}<0.05$. T-tests for independent measures were performed to analyze differences between sexes. Threshold values for Cohen effect sizes (ES) were: $<0.2$ trivial, 0.2 a 0.6 small, 0.6 a 1.2 moderate and $>1.2$ large (Hopkins, Marshall, Batterham, \& Hanin, 2009). Pearson correlation was performed to analyze correlation levels between the leg power variables and anthropometric ones. Effect size was calculated to measure them, using the following scale: $<0.10$ trivial, 0.10 a 0.29 
Lago-Fuentes, C.; Pérez-Celada, S.; Prieto-Troncoso P.; Rey, E., \& Mecías-Calvo, M. (2020). Anthropometric and conditional profile in semiprofessional futsal players: differences between sexes. A case study. RICYDE. Revista Internacional de Ciencias del Deporte. 61(16), 330-341. https://doi.org/10.5232/ricyde2020.06107

small, 0.30 a 0.49 moderate, 0.50 a 0.69 large 0.70 a 0.89 very large and $>0.90$ almost perfect (Hopkins et al., 2009).

\section{Results}

The tables and figures of statistical data processing will be presented below. Due to the large amount of obtained results, only those that have been considered more relevant are presented.

Table 2. Anthropometric and conditional profile of futsal players regarding sexes

Females $(\mathbf{n}=11)$

Males (n=8)

$\mathbf{E S}^{4}$

\begin{tabular}{|c|c|c|c|c|c|c|}
\hline Anthropometric variables & Mean \pm SD & IC (90\%) & Mean \pm SD & IC (90\%) & & \\
\hline$\%$ Fat & $20.12 \pm 3.46$ & $18.22-22.01$ & $10.2 \pm 2.41$ & $8.58-11.81$ & $3.33^{* *}$ & Large \\
\hline$\%$ Muscle mass & $44.89 \pm 3.31$ & $43.08-46.69$ & $50.83 \pm 2.14$ & $49.40-52.27$ & $2.13 * *$ & Large \\
\hline$\%$ Bone & $14.1 \pm 0.85$ & $13.63-14.56$ & $14.87 \pm 0.92$ & $14.25-15.48$ & 0.87 & Moderate \\
\hline$\%$ Residual & $20.9 \pm 0.00$ & - & $24.1 \pm 0.00$ & - & $-* *$ & - \\
\hline \multicolumn{7}{|l|}{ Somatotype } \\
\hline Endomorphic & $4.36 \pm 1.027$ & $3.8-4.91$ & $2.63 \pm 0.74$ & $2.11-3.04$ & $1.93^{* *}$ & Large \\
\hline Mesomorphic & $4.09 \pm 0.83$ & $3.57-4.43$ & $4.75 \pm 1.58$ & $3.56-5.61$ & 0.52 & Small \\
\hline Ectomorphic & $2.00 \pm 0.89$ & $1.51-2.42$ & $2.13 \pm 1.13$ & $1.41-2.47$ & 0.13 & Trivial \\
\hline Somatotype & $2.73 \pm 1.27$ & $2.03-3.42$ & $5.38 \pm 2.56$ & $3.66-7.09$ & $1.31^{* *}$ & Large \\
\hline \multicolumn{7}{|l|}{ Leg power } \\
\hline SJ Height $^{1}$ & $24.76 \pm 3.84$ & $22.66-26.68$ & $36.36 \pm 4.8$ & $33.15-39.76$ & $2.67 * *$ & Large \\
\hline SJ Flight ${ }^{2}$ & $449.1 \pm 34.92$ & $430.24-467.94$ & $544.0 \pm 35.49$ & $519.98-568.02$ & $2.70 * *$ & Large \\
\hline CMJ Height $^{1}$ & $27.32 \pm 4.1$ & $25.08-29.55$ & $37.49 \pm 3.84$ & $34.91-40.06$ & $2.56^{* *}$ & Large \\
\hline CMJ Flight $^{2}$ & $471.64 \pm 34.96$ & $452.53-490.75$ & $552.63 \pm 29.41$ & $532.92-572.33$ & $2.51 * *$ & Large \\
\hline \multicolumn{7}{|l|}{ Range of motion } \\
\hline Right gluteus $^{3}$ & $131.09 \pm 8.96$ & 126.19-135.99 & $136.13 \pm 11.01$ & $128.75-143.50$ & 0.50 & Small \\
\hline Left gluteus ${ }^{3}$ & $133.18 \pm 6.35$ & $129.71-136.65$ & $135.63 \pm 9.93$ & $128.98-142.27$ & 0.29 & Small \\
\hline Right psoas $^{3}$ & $11.55 \pm 1.37$ & $10.80-12.29$ & $10.75 \pm 1.99$ & $9.42-12.08$ & 0.47 & Small \\
\hline Left psoas ${ }^{3}$ & $11.46 \pm 1.57$ & $10.60-12.31$ & $10.25 \pm 1.39$ & $9.32-11.18$ & 0.82 & Moderate \\
\hline
\end{tabular}

${ }^{1}$ in $\mathrm{cm} ;{ }^{2}$ in $\mathrm{ms} ;{ }^{3}$ in degrees; ${ }^{4}$ Effect size; ${ }^{*} \mathrm{p}<0.05 ; * * \mathrm{p}<0.01$

Table 2 shows the differences among anthropometric and conditional profile regarding sexes. As great anthropometric differences, there stand out the fat and muscular percentages, as well as the somatotypical differences, noticing in female players a meso-endomorphic tendency and in male players a mesomorphic one (represented in Figure 2). Regarding the leg power, significant differences were observed in all measured variables, in height and in flight time/duration, in both kinds of jumps, SJ and CMJ. Finally, there are no significant differences in the flexibility values in the muscle groups tested on either side. There is greater flexibility in gluteus in men, as well as greater flexibility in psoas in women, with a small or moderate size effect. 
Lago-Fuentes, C.; Pérez-Celada, S.; Prieto-Troncoso P.; Rey, E., \& Mecías-Calvo, M. (2020). Anthropometric and conditional profile in semiprofessional futsal players: differences between sexes. A case study. RICYDE. Revista Internacional de Ciencias del Deporte. 61(16), 330-341. https://doi.org/10.5232/ricyde2020.06107

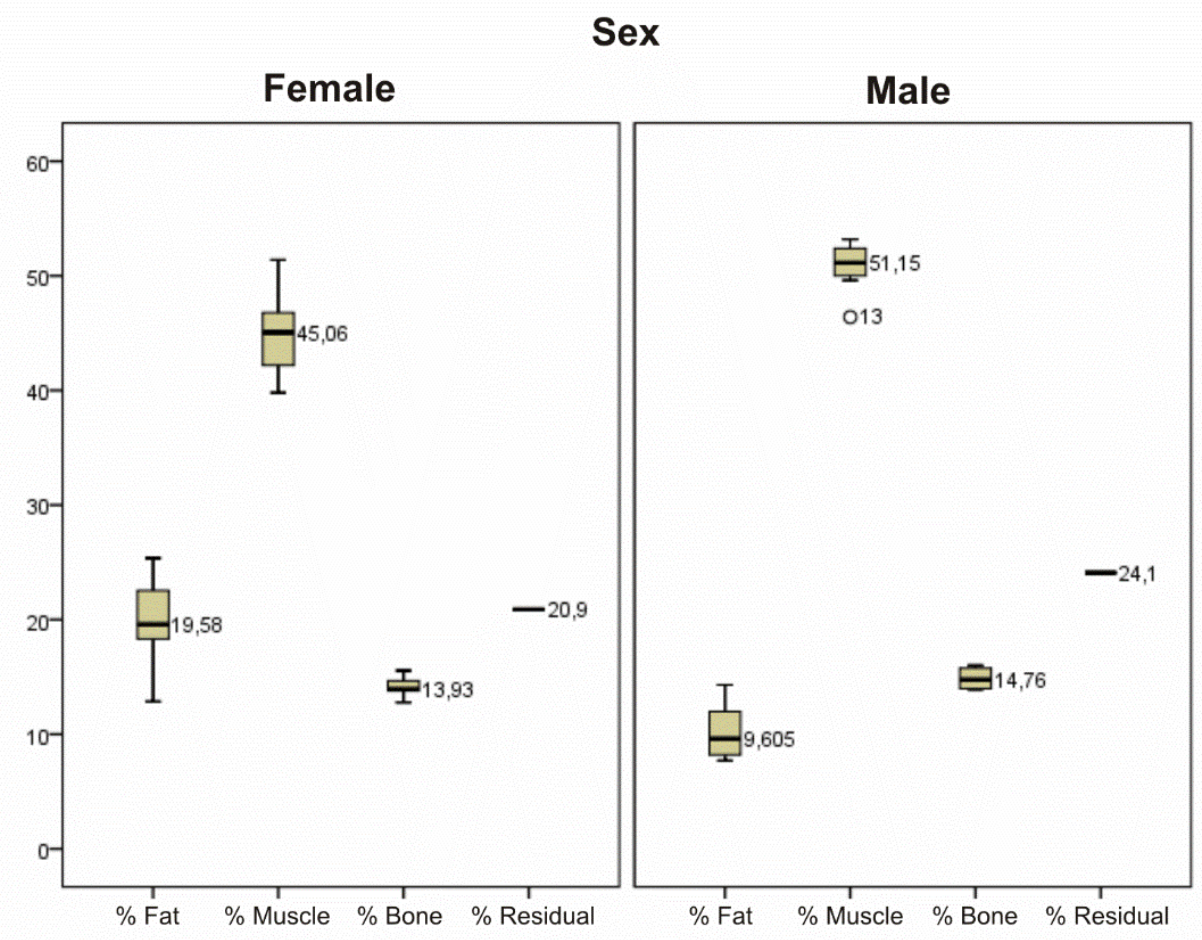

Figure 1. Body composition regarding sexes

Figure 1 shows the greater fat percentage in female players over male ones, meanwhile more muscle percentage was reported in male futsal players.
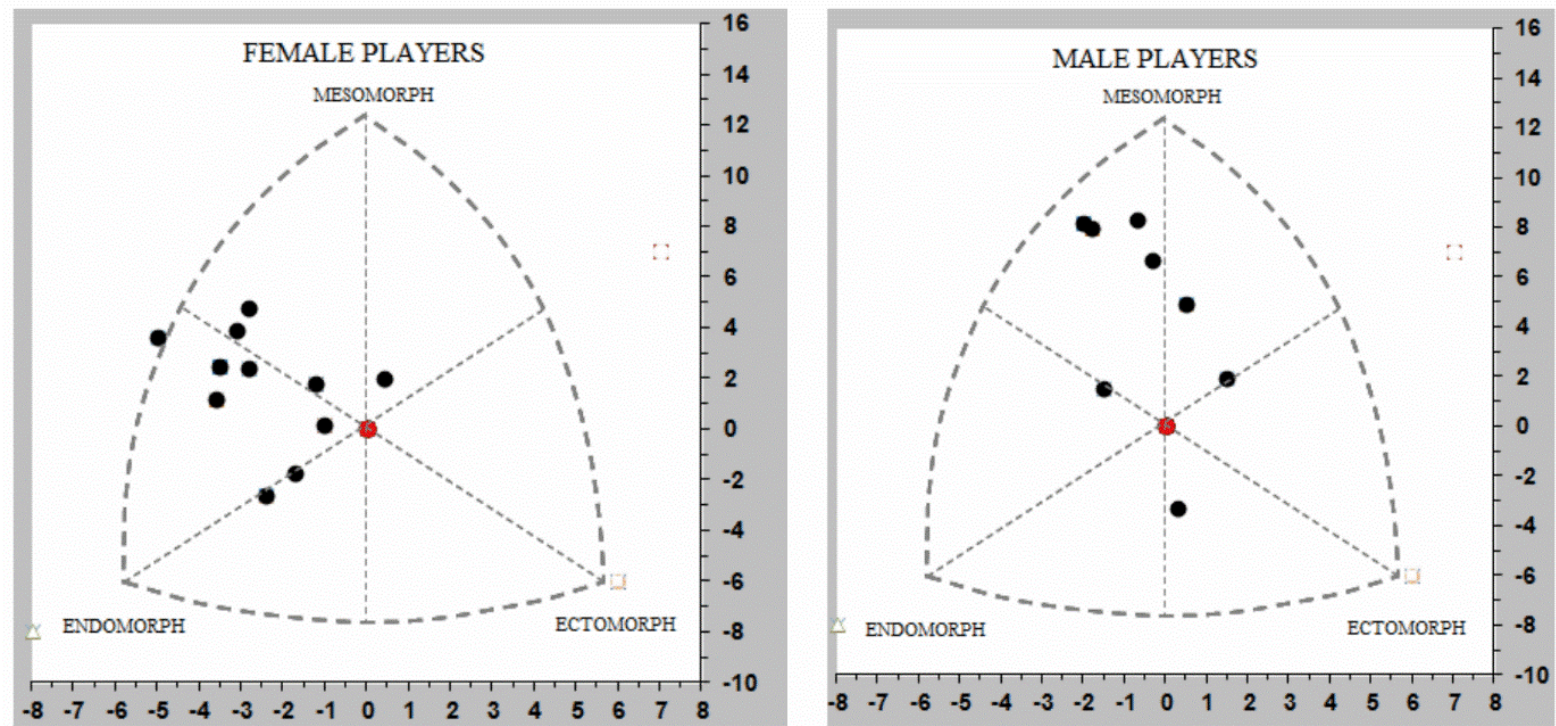

Figure 2. Somatochart of female and male futsal players 
Lago-Fuentes, C.; Pérez-Celada, S.; Prieto-Troncoso P.; Rey, E., \& Mecías-Calvo, M. (2020). Anthropometric and conditional profile in semiprofessional futsal players: differences between sexes. A case study. RICYDE. Revista Internacional de Ciencias del Deporte. 61(16), 330-341. https://doi.org/10.5232/ricyde2020.06107

Table 3 shows the relations between the main explosive performance variables and anthropometric one. Thus, it is observed the inverse relation between explosive actions and fat percentage, as well as the positive relation between these actions and the muscle percentage.

Table 3. Correlations between leg power and anthropometric variables

\begin{tabular}{|c|c|c|c|c|c|c|}
\hline \multirow[t]{2}{*}{ Variable } & \multicolumn{2}{|c|}{$\%$ Body Fat } & \multicolumn{2}{|c|}{$\%$ Muscle mass } & \multicolumn{2}{|c|}{$\mathbf{B M I}^{2}$} \\
\hline & Pearson & $\mathrm{ES}^{1}$ & Pearson & $\mathrm{ES}^{1}$ & Pearson & $\mathrm{ES}^{1}$ \\
\hline SJ height & $-0.848 * *$ & Very large & $0.731^{* *}$ & Very large & 0.134 & Small \\
\hline CMJ height & $-0.832 * *$ & Very large & $0.736^{* *}$ & Very large & 0.113 & Small \\
\hline
\end{tabular}

\section{Discussion}

This is the first study to describe anthropometrical characteristics, ROM and leg power in male and female sub-elite futsal teams. The main results of this study were: a) men presented a significant lower fat percentage than women; b) men reached higher values regarding the leg power with respect to women; c) no significant differences were found concerning the ROM levels between sexes; d) there is an inverse correlation between the fat percentage and the leg power in both sexes; and e) there is a positive correlation between the muscular percentage and the leg power in both sexes.

The leg power is a vital capacity in futsal due to its constant short-term actions and number of accelerations and decelerations (Dogramaci, Watsford, \& Murphy, 2011). The results of this study showed lower values, both in men and women compared with previous studies in futsal (Silva et al., 2012). These differences can be explained by the different training and competition levels, since the studies mentioned above analyzed professional athletes. This can also be due to an important deficiency in the elastic-explosive strength training, which is crucial in futsal performance. For this reason, applying specific training methods to improve leg power in these categories is necessary. Analyzing sex differences, our results match with previous studies (Mangine et al., 2014; Piscitelli, Milanese, Sandri, Cavedon, \& Zancanaro, 2016). This can be related to the different musculoskeletal structure and the anaerobic performance associated to the sex in athletes, both professionals and amateurs (Mangine et al., 2014), which suggests different levels of muscle mass and, consequently, strength produced in accordance with the sex (Saladin, 2011). As it was indicated previously, coaches should adapt and include more strength training during their weekly sessions to improve the leg power, which has been associated with performance level in female futsal (Ramos-Campo et al., 2016), and has been described as a very common training in professional futsal teams (Lago-Fuentes et al., 2020).

The ROM is another relevant factor in futsal because it allows the performance of explosive movements with great amplitude, also related with injury prevention strategies (Cejudo et al., 2014; Cejudo, Sainz de Baranda, Ayala, \& Santonja, 2015; Sainz de Baranda et al., 2015). In the current study, significant differences in ROM levels between male and female players were not found. Furthermore, these values in both sexes reached by the tested muscular groups, both in the left and right limbs, are comparable to previous results by the subjects of 
Lago-Fuentes, C.; Pérez-Celada, S.; Prieto-Troncoso P.; Rey, E., \& Mecías-Calvo, M. (2020). Anthropometric and conditional profile in semiprofessional futsal players: differences between sexes. A case study. RICYDE. Revista Internacional de Ciencias del Deporte. 61(16), 330-341. https://doi.org/10.5232/ricyde2020.06107

other studies, although slightly lower injuries (Cejudo et al., 2014; Sainz de Baranda et al., 2015). This can be explained because the semi-professional sample does not reach optimal ranges in sport, or that the teams analyzed do not include a specific work in their training sessions to improve these levels. Furthermore, a recent study has been shown that elite futsal teams do not include flexibility training as one of the main exercise in their injury prevention programs, which can explain the low levels performed in our study (Lago-Fuentes et al., 2020). Further studies should emphasize the mobility and/or flexibility training in order to increase their the hip ROM to reach the ranks obtained in other studies referents in futsal injuries (Cejudo et al., 2014; Sainz de Baranda et al., 2015).

Since futsal is a high-intensity, intermittent sport (Castagna et al., 2009), players must have reduced fat percentages to optimize their efforts. The results of the present study have shown lower values of fat percentage than in previous researches, such as Bahamondes et al. (2012), in which they reported a body fat percentage over 30\% in female sub17 soccer players in similar categories or with elite and sub-elite female futsal players $(>26 \%)$ (Ramos-Campo et al., 2016). Nevertheless, these values are superior than in professional female futsal players (15-18\%) (Barbero Álvarez et al., 2015; Da Rocha et al., 2015; Teixeira et al., 2019). This seems to confirm the indicated by Barbieri et al. (2012) in their study with Brazilian Second Division players and semi-professionals of a lower category that the level and the training volume are influential factors in the fat percentage of futsal athletes. This characteristic depends on the sport, because in other ones like golf, there was not any significative differences between amateur and professional players (Son et al., 2018). On the other hand, male players presented a similar percentage to that of other studies made with professional players (Matzenbacher et al., 2014; Rodrigues et al., 2011), and a lower percentage to the ones obtained in studies with semi-professional players, such as the one carried out by Barbieri et al. (2012). This, as in the case of female players, can imply a competitive advantage due to a good level of fat percentage can influence positively on athlete performance. The differences in the fat percentage between male and female players in our study are significant, a factor associated with the anthropometric characteristics of each sex (Piscitelli et al., 2016). Regarding the somatotype, it is observed that women present a higher endomorphic component than men, while men present higher values in mesomorphic and ectomorphic components. These values are related with the differences in the distribution of the body composition associated to the sex, as indicated by Piscitelli et al. (2016) with handball players.

Several studies have highlighted the inverse relationship between fat percentage and sport efficiency (Abad et al., 2016; Fontana, Colosio, Da Lozzo, \& Pogliaghi, 2016). In our study, it was reported a very strong inverse correlation between the fat percentage and the efficiency in $\mathrm{SJ}$ and $\mathrm{CMJ}$, according with previous studies in female professional rugby players $(\mathrm{r}=-$ 0.625) (Jones et al., 2016), male sub17 football players ( $\mathrm{r}=-0.85$ in $\mathrm{SJ}$ and $\mathrm{r}=-0.92$ in $\mathrm{CMJ}$ ) (Abad et al., 2016), and in male basketball players with moderated correlation values in SJ and CMJ ( $\mathrm{r}=-0.494$ and $\mathrm{r}=-0.487$, respectively) (Alemdaroglu, 2012). Thus, presenting a reduced fat percentage during the competitive period, regardless of the sex, can increase the efficiency in explosive actions, which is a key factor in futsal. For these reasons, having a somatotype profile with an associated fat percentage level in each sportive level and sex category can help to adapt the demands during pre-season and in-season periods by technical staff. 
Lago-Fuentes, C.; Pérez-Celada, S.; Prieto-Troncoso P.; Rey, E., \& Mecías-Calvo, M. (2020). Anthropometric and conditional profile in semiprofessional futsal players: differences between sexes. A case study. RICYDE. Revista Internacional de Ciencias del Deporte. 61(16), 330-341. https://doi.org/10.5232/ricyde2020.06107

Conversely to the fat percentage, good levels of muscle mass have been associated with a higher athletic performance (Mangine et al., 2014). Thus, our results match with the study of Mangine et al. (2014) who reported that a higher muscle mass was directly correlated with a higher power in jump and sprint. In this study, authors pointed out that there are differences between the muscle mass and strength in favor of men with respect to women, but, however, there are no significant differences in the relative values. This matches with our results, as there are relevant differences between the leg power between sexes, in both height and flight time. In this sense, relative values help to signal the relevance to individualize the exigencies of each sport modality and not to underestimate female performance. As a practical application, evaluating the anthropometric and conditional profile of futsal players has a direct transference for technical staff, due to they will be able to demand to their athletes optimal ranges to optimize their efficiency in explosive actions, one of the key factors in the futsal performance (Dogramaci et al., 2011), as well as to adapt their training plans to these needs both in male and female categories. However, this study has some limitations, as the sample size, as well as the low number of performance tests. For these reasons, further studies should include players of different categories in both sexes to define the somatotype according to each level and specific position. Also, other relevant and specific tests in futsal should be included to analyze $\mathrm{RSA}$ or $\mathrm{VO}_{2} \mathrm{max}$, as well as to define the interlimb asymmetries tests.

\section{Conclusion}

Our study shows that male futsal players reported a greater mesomorphic and ectomorphic component, reflected through their greater muscle mass, whereas female futsal players presented a greater endomorphic component, with higher fat percentage values. The performance on SJ and CMJ was greater in sub-elite male futsal players with respect to the female ones, although gluteus and iliopsoas flexibility levels did not report significant differences between sexes. Finally, lower fat percentage and higher muscular percentage was associated with a higher performance in SJ and CMJ, in both sexes in sub-elite futsal players. This data could be useful for coaches and technical staffs on these categories to demand their players an optimal anthropometrical and conditional profile as well as to adapt their individualized training plans along the season.

\section{References}

Abad, C.; Cuniyochi, R.; Kobal, R.; Gil, S.; Pascoto, K.; Nakamura, F. \& Loturco, I. (2016). Effect of detraining on body composition, vertical jumping ability and sprint performance in young elite soccer players. Revista Andaluza de Medicina Del Deporte, 9(3), 124-130. https://doi.org/10.1016/j.ramd.2015.03.003

Alemdaroglu, U. (2012). The relationship between muscle strength, anaerobic performance, agility, sprint ability and vertical jump performance in professional basketball players. Journal of Human Kinetics, 31(1), 149-158. https://doi.org/10.2478/v10078-012-0016-6

Arins, F. B.; Salvador, P. C.; Carminatti, L. J. \& Guglielmo, L. G. (2015). Physiological characteristics, evaluation and prescription of aerobic training in Futsal. Revista Brasileira de Cineantropometria \& Desempenho Humano, 17(6), 753-762. https://doi.org/10.5007/1980-0037.2015v17n6p753

Ayala, F.; Sainz de Baranda, P.; De Ste Croix, M. \& Santonja, F. (2012). Absolute reliability of five clinical tests for assessing hamstring flexibility in professional futsal players. Journal of Science and Medicine in Sport, 15(2), 142-147. https://doi.org/10.1016/j.jsams.2011.10.002 
Lago-Fuentes, C.; Pérez-Celada, S.; Prieto-Troncoso P.; Rey, E., \& Mecías-Calvo, M. (2020). Anthropometric and conditional profile in semiprofessional futsal players: differences between sexes. A case study. RICYDE. Revista Internacional de Ciencias del Deporte. 61(16), 330-341. https://doi.org/10.5232/ricyde2020.06107

Bahamondes Avila, C.; Cifuentes Cea, B. M.; Lara Padilla, E., \& Berral de la Rosa, F. J. (2012). Composición corporal y somatotipo en futbol femenino: Campeonato Sudamericano Sub-17. International Journal of Morphology, 30(2), 450-460. http://dx.doi.org/10.4067/S0717-95022012000200016

Barbero Álvarez, J. C.; Subiela, J.; Granda-Vera, J.; Castagna, C.; Gómez, M., \& Del Coso, J. (2015). Aerobic fitness and performance in elite female futsal players. Biology of Sport, 32(4), 339-344.

http://doi.org/10.5604/20831862.1189200

Barbieri, F. A.; Barbieri, R. A.; Queiroga, M. R.; Santana, W. C., \& Kokubun, E. (2012). Anthropometrical and physiological profile of futsal players of the under-20 and adults categories. Motricidade, 8(4), 62-70.

https://doi.org/10.6063/motricidade.8(4).1553

Bosco, C.; Komi, P. V.; Tihanyi, J.; Fekete, G., \& Apor, P. (1983). Mechanical power test and fiber composition of human leg extensor muscles. European Journal of Applied Physiology and Occupational Physiology, 51(1), 129-135.

https://doi.org/10.1007/BF00952545

Bruinvels, G.; Burden, R.; McGregor, A.; Ackerman, K. A.; Dooley, M.; Richards, T., \& Pedlar, C. (2017). Sport, exercise and the menstrual cycle: where is the research? British Journal of Sports Medicine, 51(6), 487-488.

https://doi.org/10.1136/bjsports-2016-096279

Castagna, C.; D’Ottavio, S.; Grande Vera, J., \& Barbero Álvarez, J. C. (2009). Match demands of professional Futsal: A case study. Journal of Science and Medicine in Sport, 12(4), 490-494.

https://doi.org/10.1016/j.jsams.2008.02.001

Cejudo, A.; Sainz de Baranda, P.; Ayala, F., \& Santonja, F. (2014). Flexibility profile of lower-limb muscle in futsal players. Revista Internacional de Medicina y Ciencias de La Actividad Física y Del Deporte, 14(55), 509-525.

Cejudo, A.; Sainz de Baranda, P.; Ayala, F., \& Santonja, F. (2015). Test-retest reliability of seven common clinical tests for assessing lower extremity muscle flexibility in futsal and handball players. Physical Therapy in Sport, 16(2), 107-113. https://doi.org/10.1016/j.ptsp.2014.05.004

Da Rocha, R. E. R.; Nunes, E. A., \& Venera, G. D. (2015). Selective loads periodization attenuates biochemical disturbances and enhances performance in female futsal players during competitive season. Motriz. Revista de Educacao Fisica, 21(2), 158167.

https://doi.org/10.1590/S1980-65742015000200006

Dogramaci, S. N.; Watsford, M. L., \& Murphy, A. J. (2011). Time-motion analysis of international and national level futsal. Journal of Strength and Conditioning Research, 25(3), 646-651.

https://doi.org/10.1519/JSC.0b013e3181c6a02e

FIFA. (2018). Women's football strategy. Retrieved from: https://resources.fifa.com/image/upload/women-s-football strategy. pdf?cloudid=z7w21ghir8jb9tguvbcq

Fontana, F. Y.; Colosio, A. L.; Da Lozzo, G., \& Pogliaghi, S. (2016). Player's success prediction in rugby union: From youth performance to senior level placing. Journal of Science and Medicine in Sport.

https://doi.org/10.1016/j.jsams.2016.08.017 
Lago-Fuentes, C.; Pérez-Celada, S.; Prieto-Troncoso P.; Rey, E., \& Mecías-Calvo, M. (2020). Anthropometric and conditional profile in semiprofessional futsal players: differences between sexes. A case study. RICYDE. Revista Internacional de Ciencias del Deporte. 61(16), 330-341. https://doi.org/10.5232/ricyde2020.06107

Galy, O.; Zongo, P.; Chamari, K.; Chaouachi, A.; Michalak, E.; Dellal, A.; ... Hue, O. (2015). Anthropometric and physiological characteristics of Melanesian futsal players: a first approach to talent identification in Oceania. Biology of Sport, 32(2), 135-141. https://doi.org/10.5604/20831862.1140428

Hopkins, W.; Marshall, S.; Batterham, A., \& Hanin, J. (2009). Progressive statistics for studies in sports medicine and exercise science. Medicine Science in Sports Exercise, 41(1), 3.

https://doi.org/10.1249/MSS.0b013e31818cb278

Jones, B.; Emmonds, S.; Hind, K.; Nicholson, G.; Rutherford, Z., \& Till, K. (2016). Physical qualities of international female rugby league players by playing position. Journal of Strength and Conditioning Research, 30(5), 1333-1340. https://doi.org/10.1519/JSC.0000000000001225

Karavelioglu, M. B.; Harmanci, H.; Kaya, M., \& Erol, M. (2016). Effects of Plyometric Training on Anaerobic Capacity and Motor Skills in Female Futsal Players. Anthropologist, 23(30), 355-360.

https://doi.org/ 10.1080/09720073.2014.11891955

Lago-Fuentes, C., Jiménez-Loaisa, A., Padrón-Cabo, A., Mecías-Calvo, M., \& Rey, E. (2020). Perceptions of the technical staff of professional teams regarding injury prevention in Spanish national futsal leagues: a cross-sectional study. Peer], 8, e8817.

https://doi.org/10.7717/peerj.8817

Lago-Fuentes, C.; Rey, E.; Padrón-Cabo, A.; De Rellán-Guerra, A. S.; FragueiroRodríguez, A., \& García-Núñez, J. (2018). Effects of core strength training using stable and unstable surfaces on physical fitness and functional performance in professional female futsal players. Journal of Human Kinetics, 65(1). https://doi.org/10.2478/hukin-2018-0029

Mangine, G. T.; Fukuda, D. H.; LaMonica, M. B.; Gonzalez, A. M.; Wells, A. J.; Townsend, J. R.; ... Hoffman, J. R. (2014). Influence of gender and muscle architecture asymmetry on jump and sprint performance. Journal of Sports Science \& Medicine, 13(4), 904-911.

Marfell-Jones, M. J., Stewart, A. D., \& de Ridder, J. H. (2012). International standards for anthropometric assessment. Wellington, New Zealand: International Society for the Advancement of Kinanthropometry.

Matzenbacher, F.; Pasquarelli, B. N.; Rabelo, F. N., \& Stanganelli, L. C. R. (2014). Demanda fisiológica no futsal competitivo: características físicas e fisiológicas de atletas profissionais. Revista Andaluza de Medicina Del Deporte, 7(3), 122-131. https://doi.org/10.1016/S1888-7546(14)70074-7

Milić, M.; Grgantov, Z.; Chamari, K.; Ardigò, L. P.; Bianco, A., \& Padulo, J. (2017). Anthropometric and physical characteristics allow differentiation of young female volleyball players according to playing position and level of expertise. Biology of Sport, 34(1), 19.

https://doi.org/10.5114/biolsport.2017.63382

Naser, N.; Ali, A., \& Macadam, P. (2017). Physical and physiological demands of futsal. Journal of Exercise Science \& Fitness, 15(2), 76-80.

https://doi.org/10.1016/j.jesf.2017.09.001

Piscitelli, F.; Milanese, C.; Sandri, M.; Cavedon, V., \& Zancanaro, C. (2016). Investigating predictors of ball-throwing velocity in team handball: the role of sex, anthropometry, and body composition. Sport Sciences for Health, 12(1), 11-20. https://doi.org/10.1007/s11332-015-0248-7 
Ramos-Campo, D. J.; Sánchez, F. M.; García, P. E.; Arias, J. A. R.; Cerezal, A. B., Clemente-Suarez, V. J., \& Díaz, J. F. J. (2014). Body composition features in different playing position of professional team indoor players: Basketball, handball and futsal. International Journal of Morphology, 32(4), 1316-1324.

https://doi.org/10.4067/S0717-95022014000400032

Ramos-Campo, D. J.; Rubio-Arias, J. A.; Carrasco-Poyatos, M., \& Alcaraz, P. E. (2016). Physical performance of elite and subelite Spanish female futsal players. Biology of sport, 33(3), 297. https://doi.org/10.5604/20831862.1212633

Rodrigues, V.; Ramos, G.; Mendes, T.; Cabido, C.; Melo, E.; Condessa, L.; ... Garcia, E. (2011). Intensity of Official Futsal Matches. Journal of Strength and Conditioning Research, 25(9), 2482-2487. https://doi.org/10.1519/JSC.0b013e3181fb4574

Sainz de Baranda, P.; Cejudo, A.; Ayala, F., \& Santonja, F. (2015). Optimum profile of lower-limb muscle flexibility in female futsal players. Revista Internacional de Medicina y Ciencias de La Actividad Física y Del Deporte, 15(60), 647-662. http://dx.doi.org/10.15366/rimcafd2015.60.003

Saladin, K. S. (2011). Anatomy and Physiology: The Unity of Form and Function (6th ed.). McGraw--Hill Higher Educa_on, New York, New York.

Silva, J. F.; Detanico, D.; Floriano, L. T.; Dittrich, N.; Nascimento, P. C.; Santos, S. G., \& Guglielmo, L. G. (2012). Níveis de potência muscular em atletas de futebol e futsal em diferentes categorias e posições. Motricidade, 8(1), 14. http://dx.doi.org/10.6063/motricidade.8(1).233

Teixeira, A.; Marine, D. A.; Dominguos, M. M.; Bertucci, D. R.; Cury, M. F.; Botero, J. P., \& Leite, R. D. (2014). Caracterização da composição corporal, potência aeróbia, anaeróbia e força de membros inferiores de adolescentes praticantes de futsal com diferentes frequências semanais de treinamento. Revista Brasileira de Reabilitação e Atividade Física, 3(1). https://doi.org/10.13140/RG.2.2.22591.41129

Teixeira, A. S.; Arins, F. B.; De Lucas, R. D.; Carminatti, L. J.; Dittrich, N.; Nakamura, F. Y., \& Guglielmo, L. G. A. (2019). Comparative effects of two interval shuttle-run training modes on physiological and performance adaptations in female professional futsal players. The Journal of Strength \& Conditioning Research, 33(5), 1416-1428. https://doi.org/10.1519/JSC.0000000000002186

Vidal Andreato, L.; Del Conti Esteves, J. V.; Alves De Souza, E.; Magnani Branco, B. H.; Leme Gonçalves Panissa, V., \& Franzói De Moraes, S. M. (2013). Anthropometric and motor characteristics of Brazilian futsal athletes at state level. Medicina Dello Sport, $66(2), 211-221$. 